\title{
Subcutaneously Administered Ofatumumab in Rheumatoid Arthritis: A Phase I/II Study of Safety, Tolerability, Pharmacokinetics, and Pharmacodynamics
}

\author{
Regina Kurrasch, Judith C. Brown, Myron Chu, Jenny Craigen, Philip Overend, Bela Patel, \\ Steven Wolfe, and David J. Chang
}

\begin{abstract}
Objective. To investigate the safety and tolerability of a single subcutaneous (SC) dose of ofatumumab, a fully human anti-CD20 monoclonal antibody, in patients with rheumatoid arthritis (RA) taking background methotrexate (MTX). Secondary objectives included characterizing pharmacokinetics and pharmacodynamics.

Methods. In this single-blind, phase I/II study, 35 patients with RA were randomized in 5 cohorts to receive a single subcutaneous (SC) ofatumumab dose ranging from 0.3 to $100 \mathrm{mg}$, or placebo, following premedication with oral acetaminophen and antihistamine. Patients were followed for 24 weeks with extended followup to monitor B cell and immunoglobulin recovery for up to 2 years if required.

Results. Thirty-five patients received the following treatment: $0.3 \mathrm{mg}, \mathrm{n}=4 ; 3 \mathrm{mg}, \mathrm{n}=6 ; 30 \mathrm{mg}$, $\mathrm{n}=8 ; 60 \mathrm{mg}, \mathrm{n}=6 ; 100 \mathrm{mg}, \mathrm{n}=3 ;$ placebo, $\mathrm{n}=8$. The most common adverse events in the combined ofatumumab groups were headache, nausea, and upper respiratory tract infection. Because of tolerability concerns, only 3 patients were given $100 \mathrm{mg}$. For the $30-100 \mathrm{mg}$ doses, median maximum plasma concentration values ranged from 4.02 to 4.49 days. Mean elimination half-life values ranged from 5.20 to 6.83 days. Increasing peripheral median B cell depletion was observed from $0.3 \mathrm{mg}$ up to $30 \mathrm{mg}$, and full target B cell depletion was achieved with $30 \mathrm{mg}, 60 \mathrm{mg}$, and $100 \mathrm{mg}$.

Conclusion. Treatment of RA patients with SC ofatumumab doses of $30 \mathrm{mg}$ or higher resulted in profound and prolonged B cell depletion in blood. Single doses up to $60 \mathrm{mg}$ were tolerated without glucocorticoid premedication. (ClinicalTrials.gov identifier NCT00686868) (First Release June 1 2013; J Rheumatol 2013;40:1089-96; doi:10.3899/jrheum.121118)
\end{abstract}

Key Indexing Terms:

CLINICAL TRIALS

PHARMACOKINETICS

B LYMPHOCYTES

RHEUMATOID ARTHRITIS

BIOLOGICAL THERAPY

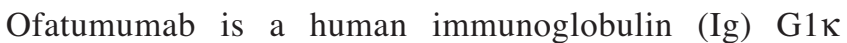
monoclonal antibody (mAb) that specifically binds to the human CD20 antigen inducing potent B cell lysis. Ofatumumab recognizes a membrane-proximal epitope on the human CD20 molecule, distinct from the epitope recognized by rituximab, a chimeric $\mathrm{mAb}$, and other anti-CD20 $\mathrm{mAb} b^{1,2,3}$. The membrane proximity of this epitope is likely to account for the high efficiency of B cell lysis observed

From GlaxoSmithKline (GSK), King of Prussia, Pennsylvania, USA Stockley Park, UK; Stevenage, UK; and Research Triangle Park, North Carolina, USA.

Sponsored by GlaxoSmithKline.

R. Kurrasch, MD, MPH, GSK, King of Prussia, PA; J.C. Brown, PhD, GSK, Stockley Park, UK; M. Chu, DO, GSK, King of Prussia, Pennsylvania, USA; J. Craigen, PhD; P. Overend, BSc, GSK, Stevenage, UK; B. Patel, PhD, GSK, King of Prussia, PA; S. Wolfe, MS, GSK, Research Triangle Park, NC; D.J. Chang, MD, MPH, GSK, King of Prussia, PA.

Address correspondence to Dr. R. Kurrasch, 2301 Renaissance Blvd., RN0320, King of Prussia, PA 19406, USA. E-mail: regina.h.kurrasch@gsk.com

Full Release Article. For details see Reprints/Permissions at jrheum.org Accepted for publication March 27, 2013. with ofatumumab in both in vitro and in vivo preclinical studies $^{4,5,6}$. Ofatumumab induces B cell depletion primarily through complement-dependent cytotoxicity and antibody-dependent cell-mediated cytotoxicity with in vitro potencies $\left(\mathrm{EC}_{50}\right)$ estimated at $600 \mathrm{ng} / \mathrm{ml}$ and $20 \mathrm{ng} / \mathrm{ml}$, respectively ${ }^{7}$. Ofatumumab by intravenous (IV) infusion is approved for the treatment of chronic lymphocytic leukemia refractory to fludarabine and alemtuzumab.

In a previous randomized, placebo-controlled phase I/II study, IV ofatumumab doses of $300 \mathrm{mg}, 700 \mathrm{mg}$, and 1000 mg administered as 2 infusions 2 weeks apart demonstrated significant clinical benefit compared with placebo in patients with active rheumatoid arthritis (RA) who had an inadequate response to disease-modifying antirheumatic drugs (DMARD) ${ }^{8}$.

Infusion reactions, resulting from rapid B cell depletion and cytokine release, are commonly observed and may be severe following IV administration of anti-CD20 therapy, as has been reported in a phase I/II ofatumumab study in patients with $\mathrm{RA}^{8}$. Approaches including increased volume of infusion, increased infusion time, and use of IV gluco-

Personal non-commercial use only. The Journal of Rheumatology Copyright $\odot$ 2013. All rights reserved. 
corticoid premedication successfully reduced the incidence and severity of infusion reactions observed with ofatumumab, a highly potent monoclonal antibody with enhanced complement-dependent effector ${ }^{8,9}$. A study of ocrelizumab, a humanized anti-CD20 monoclonal antibody with enhanced antibody-dependent cell-mediated cytotoxicity and reduced complement-dependent cytotoxicity, administered IV to patients with RA who did not receive premedication with IV glucocorticoids, still demonstrated infusion-associated adverse events (AE) in 51\% of ocrelizumab-treated patients on the first infusion compared with $27 \%$ with placebo $^{2}$. Therefore, as an alternative to IV administration, ofatumumab, as a subcutaneous (SC) formulation, is being investigated with the aim of achieving a slower rate of absorption and B cell depletion. This may provide better safety and tolerability compared with IV administration, with no requirement for IV glucocorticoid premedication.

Although the mode of action of rituximab and ofatumumab is similar, nonclinical data indicate that ofatumumab may have a greater potential for effector activity and therefore, ofatumumab at doses lower than rituxumab may achieve similar efficacy. Indeed, the phase I/II study with IV ofatumumab demonstrated that clinical responses achieved with $300 \mathrm{mg}, 700 \mathrm{mg}$, and $1000 \mathrm{mg}$ were similar ${ }^{8}$. Our study was designed to investigate the safety and tolerability and the pharmacokinetic (PK) and pharmacodynamic (PD) effects of low doses of SC ofatumumab in patients with RA who are taking background methotrexate (MTX), without glucocorticoid premedication.

\section{MATERIALS AND METHODS}

Study design. This was a multicenter, randomized, single-blind, placebo-controlled, phase I/II study in patients with RA on stable background MTX conducted at 14 centers in Australia, Belgium, France, Italy, Poland, Russia, Spain, and the United States (ClinicalTrials.gov identifier NCT00686868). The trial was conducted in accord with good clinical practice and the Declaration of Helsinki. Ethics approval was obtained for each participating center and all patients provided informed consent.

A computer-generated randomization schedule (ofatumumab:placebo ratio 3:1 per cohort) and randomization was handled centrally through an interactive voice response system. An unblinded pharmacist prepared the injections of ofatumumab and saline placebo. Ofatumumab was supplied to the sites in prefilled glass vials as a sterile $100 \mathrm{mg} / \mathrm{ml}$ solution in acetate buffer. Investigational sites made dilutions using sterile $0.9 \%$ normal saline. All groups received a single $1 \mathrm{ml}$ volume dose of the appropriate concentration, except for the $60 \mathrm{mg}$ group, which received a $0.6 \mathrm{ml}$ dose of the $100 \mathrm{mg} / \mathrm{ml}$ solution. All doses were administered SC into the abdominal area by a 25 -gauge $\times$ half-inch needle. Eligible patients were randomized to receive a single SC dose of either ofatumumab or matching placebo following premedication with oral acetaminophen $(1000 \mathrm{mg})$ and oral antihistamine (certirizine $10 \mathrm{mg}$ or equivalent), with no planned additional glucocorticoid before or after medication. The first cohort received $30 \mathrm{mg}$, which was selected based on modeling from the IV ofatumumab PK/PD data. Dose progression and selection after $30 \mathrm{mg}$ dose cohort was based on B cell depletion data and a review of available safety and tolerability data by the sponsor, resulting in a final cohort order of $30 \mathrm{mg}, 0.3 \mathrm{mg}, 3.0 \mathrm{mg}$, $100 \mathrm{mg}$, and $60 \mathrm{mg}$. Patients in the $30 \mathrm{mg}, 60 \mathrm{mg}$, and $100 \mathrm{mg}$ cohorts were monitored in an inpatient setting for 4 days postdose and those in the lower dose cohorts for 2 days postdose, to monitor for post-injection reactions from B cell depletion. Patients were followed closely for 24 weeks after dosing, with further intermittent followup for up to 2 years to monitor for recovery of B cell counts and immunoglobulin levels, if required. The study originally had 2 parts. It was amended to remove the second part, which had planned to examine efficacy and safety of 2 doses of SC ofatumumab administered at a fixed interval, in about 30 patients with active RA, in favor of proceeding to phase II multidose studies in autoimmune indications.

Patient population. Male or female nonpregnant patients $\geq 18$ years of age with a diagnosis of RA (meeting the American College of Rheumatology 1987 revised criteria for RA) ${ }^{10}$ of at least 6 months prior to screening were eligible. There were no requirements for disease activity at baseline. Patients were required to have been treated with MTX 7.5-25 mg/week (oral, SC, or intramuscular) for at least 12 weeks prior to baseline with the last 4 weeks at a stable dosage and route, and receiving folic acid $\geq 5$ $\mathrm{mg} /$ week starting 4 weeks prior to baseline. Patients were also allowed to be treated with stable doses of oral prednisolone or equivalent up to $10 \mathrm{mg}$ per day. Patients were required to have a body mass index $<35 \mathrm{~kg} / \mathrm{m}^{2}$, $\mathrm{QTcB}$ or $\mathrm{QTcF}<450 \mathrm{~ms}$, and a negative screening chest radiograph for lung infection, including tuberculosis. Patients with previous exposure to biologic cell-depleting antirheumatic therapies were excluded. In addition, patients were required to wash out other DMARD therapy prior to baseline as follows: cyclosporine, azathioprine, sulfasalazine, penicillamine, bucillamine, hydroxychloroquine, chloroquine, at least 4 weeks; leflunomide, gold therapy, at least 12 weeks; etanercept, at least 4 weeks; infliximab, adalimumub, at least 8 weeks; abatacept, anakinra, at least 12 weeks. Exclusion criteria included other concurrent rheumatic autoimmune diseases and significant concurrent, uncontrolled medical conditions. Laboratory exclusion criteria included hemoglobin $<5.6 \mathrm{mmol} / 1(9.0 \mathrm{~g} / \mathrm{dl})$, CD19+ B cell count $<0.1 \times 10^{9} / 1$, neutrophils $<2 \times 10^{9} / 1$, platelet count $<$ $100 \times 10^{9} / 1$, serum $\operatorname{IgG}$ less than the lower limit of normal, serum alanine aminotransferase (ALT) or aspartate aminotransferase (AST) $>3$ times the upper limit of normal (ULN), serum alkaline phosphatase $>2 \times$ ULN, and serum creatinine $>133 \mu \mathrm{mol} / \mathrm{l}(1.5 \mathrm{mg} / \mathrm{dl})$. In addition, patients were excluded if they had positive test results for human immunodeficiency virus, $\mathrm{JC}$ virus, or hepatitis $\mathrm{B}$ or $\mathrm{C}$ virus at screening.

Study assessments. Vital signs (heart rate, blood pressure, and temperature), $\mathrm{AE}$, and serious adverse events (SAE) were collected up to 24 weeks. Only SAE were collected after 24 weeks. AE were coded according to the Medical Dictionary for Regulatory Activities, vol. 14. AE reported during the first week of dosing were reviewed by the sponsor and categorized as study medication injection-related systemic reactions and included fatigue, pyrexia, hyperhidrosis, flushing, flu-like symptoms, chills, nausea, vomiting, blood pressure increase, dizziness, vertigo, and liver enzyme increase. The 1-week period was selected based on the expected time to maximum ofatumumab plasma concentration $\left(\mathrm{T}_{\max }\right)$ of 4-5 days. Chest radiographs were performed at screening, if clinically indicated, and 12-lead electrocardiograms were obtained at screening and study Day 85 . Physical examinations were carried out at screening and baseline visits and during the study.

Samples were collected for hematology, clinical chemistry, routine urinalysis, pregnancy testing, plasma $\mathrm{JC}$ virus, and hepatitis $\mathrm{B}$ and $\mathrm{C}$ virus serology, and anti-drug antibody testing throughout the study. Samples for measurement of plasma ofatumumab concentrations were collected at screening, baseline, 12 h, 24 h, 48 h, 72 h, 96 h, Days 6, 7, 8, 10, 15, 22, and 29 , then every 2 weeks until Week 12 and every 4 weeks until Week 24. Samples for measurement of peripheral lymphocytes were collected at screening, baseline, 48 h, 72 h, 96 h, Days 6, 7, 8, 10, 15, 22, and 29, then every 2 weeks until Week 12 and every 4 weeks until Week 24 . If required, further samples were collected every 12 weeks to monitor for recovery of both B cell and immunoglobulin levels or for up to 2 years, whichever period was shorter.

A 4-color MultiTest T cell, B cell, and natural killer cell (TBNK) assay

Personal non-commercial use only. The Journal of Rheumatology Copyright @ $\odot$ 2013. All rights reserved. 
(BD BioSciences) was carried out on whole blood to provide absolute counts for subpopulations of lymphocytes (CD3, CD4, CD8, CD19). The lower limit of quantification (LLQ) for CD19+ B cells was 5 cells $/ \mu 1(0.005$ GI/l). Buffy coats were prepared from matched samples using standard methodology and an additional 6-color antibody panel (CD27 FITC/IgD-PE/CD19-PerCP-Cy5/CD10-PE Cy7/ CD38-APC, CD69-APC-Cy7) was used to determine B cell subset phenotypes at baseline and Days 7, 15, 22,43 , and 85 . Using quadrant gating of the CD19+ cells, the following marker combinations were reported as percentages of CD19+ B cells and as absolute counts based on the CD19 count from the TBNK panel: CD27+IgD+, CD27+IgD-, CD27-IgD-, and CD27-IgD+. Further phenotypic analyses were performed (data not shown).

Additional laboratory investigations included high- sensitivity C-reactive protein (hsCRP); erythrocyte sedimentation rate (ESR); B lymphocyte stimulator (BLyS/BAFF) and B lymphocyte chemokine (BLC; Pathway Diagnostics); interleukin 6 (IL-6); IgA, IgG, IgM; complement (CH50, C3, C4), IgM rheumatoid factor (IgM-RF), IgA-RF, and IgG-RF; anticyclic citrullinated peptide antibody (anti-CCP); and serum amyloid A (SAA; Quest Diagnostics).

Study endpoints. The primary objective was to characterize the safety and tolerability of a single SC dose of ofatumumab administered to patients with RA by assessing the incidence and severity of AE, clinical laboratory measures, and vital signs.

A key secondary objective was to determine the minimum dose of ofatumumab resulting in depletion of peripheral blood B lymphocytes $\geq$ 95\% from baseline or to below the LLQ, as measured by median change from baseline at Week 4 and/or the median value across Weeks 2-4 (i.e., the median by group of the median values over Weeks 2-4 for each individual patient). Secondary endpoints included start of and time to repletion. Repletion, for patients who achieved the target depletion (i.e., $\geq$ $95 \%$ from baseline or below the LLQ), was defined as return of B cells to either baseline level or higher, or lower limit of normal, $0.110 \mathrm{GI} / 1$ (i.e., 110 cells $/ \mathrm{mm}^{3}$ ), whichever was lower. Start of repletion for patients who achieved the target depletion was defined as B cells returning to either < $95 \%$ depletion from baseline or $\geq 0.01 \mathrm{GI} / 1$ (i.e., 10 cells $/ \mathrm{mm}^{3}, 2 \times \mathrm{LLQ}$ ), whichever was higher, for 2 consecutive samples without further depletion. Depletion and repopulation of B cell subpopulations (e.g., naive and memory phenotypes) were included as exploratory endpoints.

Other secondary endpoints included PK measures, the incidence of anti-drug antibodies, and biomarkers of disease activity and immune status.

Statistical analysis. The sample size was set based on feasibility and adequacy of data to support the development of an initial PK/PD model of CD19+ B cell depletion/repletion. There was no formal hypothesis testing. Identification of a B cell-depleting single dose of ofatumumab was achieved through use of summary statistics by dose level and visit. Three populations were considered in the analysis: (1) the safety population: all randomized patients who received the study drug; (2) the modified intent-to-treat population (mITT): all patients in the safety population who also had a baseline measurement and at least 1 posttreatment PD sample analyzed; and (3) the PK population: all patients who received study drug and had at least $1 \mathrm{PK}$ sample analyzed. Data from placebo patients in all cohorts were pooled for the final analyses.

\section{RESULTS}

Disposition and characteristics of patients. A total of 121 patients were screened for this study, of whom $86(71 \%)$ were screen failures and 35 (29\%) enrolled and were randomized (Figure 1). The most common reason for screen failure was CD19+ B cell count below the exclusion limit in $16 / 86$ patients (19\%). Of the 35 randomized patients, 27 $(77 \%)$ were exposed to ofatumumab and 35 patients were included in the safety and mITT populations. Seven of the
35 patients $(20 \%)$ withdrew from the study prematurely including 2 patients in the placebo group ( 1 because of an AE of exacerbation of arthritis and 1 lost to followup), 1 patient in the $0.3 \mathrm{mg}$ group (withdrew consent), and 4 patients in the $30 \mathrm{mg}$ group (lack of efficacy, lost to followup, withdrew consent, and study closed).

Baseline demographics and characteristics are provided in Table 1 . The majority of patients were female $(89 \%)$ and white (94\%); the mean age was 53 years (range 22-78 yrs). Sixty percent of all patients enrolled were RF-positive and $60 \%$ were anti-CCP-positive.

Safety. Table 2 summarizes the most commonly reported AE. The overall incidence of $\mathrm{AE}$ occurring during the 24-week study period was higher in the combined ofatumumab group $(24 / 27 ; 89 \%)$ compared with the placebo group $(5 / 8 ; 63 \%)$. The most commonly reported AE (i.e., those occurring in 3 or more patients in the combined ofatumumab group) were headache, nausea, upper respiratory tract infection, dizziness, hypertension, pyrexia, and RA exacerbation.

Almost all reported AE were judged by the investigators to be mild or moderate in intensity, with the exception of severe but nonserious events reported in 4 patients: headache and nausea (1 patient in the $100 \mathrm{mg}$ group), pyrexia (1 patient in the $60 \mathrm{mg}$ group), and RA exacerbation (1 patient in the $30 \mathrm{mg}$ group and 1 in the placebo group).

AE considered to be injection-related systemic reactions were more frequent in the combined ofatumumab group $(13 / 27$ patients; $48 \%)$ compared with the placebo group $(2 / 8 ; 25 \%)$ and highest in the $100 \mathrm{mg}$ ofatumumab group $(3 / 3 ; 100 \%)$. The most common injection-related systemic reactions were nausea, pyrexia or elevated body temperature, dizziness, and headache, typically in combination with another systemic reaction. These AE were of mild or moderate intensity with the exception of severe pyrexia (1 patient in the $60 \mathrm{mg}$ group) and severe nausea and headache (1 patient in the $100 \mathrm{mg}$ group). No rescue glucocorticoid was given to manage these $\mathrm{AE}$, although some patients received additional doses of oral acetaminophen or antihistamine. With the exception of liver function test elevations recorded for 1 patient in the $30 \mathrm{mg}$ group and 1 in the 100 mg group, injection-related systemic reactions resolved within about 2 days of baseline. There was no clear association between injection-related systemic reactions and use of stable low-dose concomitant corticosteroids to treat RA.

Recruitment into the $100 \mathrm{mg}$ cohort was suspended because of systemic reactions in all 3 ofatumumab-dosed patients. These AE included for Patient 1: moderate influenza-like illness within $1 \mathrm{~h}$ postdose and ALT and AST elevation at 6 days postdose; for Patient 2: mild abdominal pain, severe nausea, moderate vomiting, moderate chills, mild dizziness, and severe headache, all within $12 \mathrm{~h}$ postdose; and for Patient 3: mild headache, mild body

$$
\text { Personal non-commercial use only. The Journal of Rheumatology Copyright (c) 2013. All rights reserved. }
$$




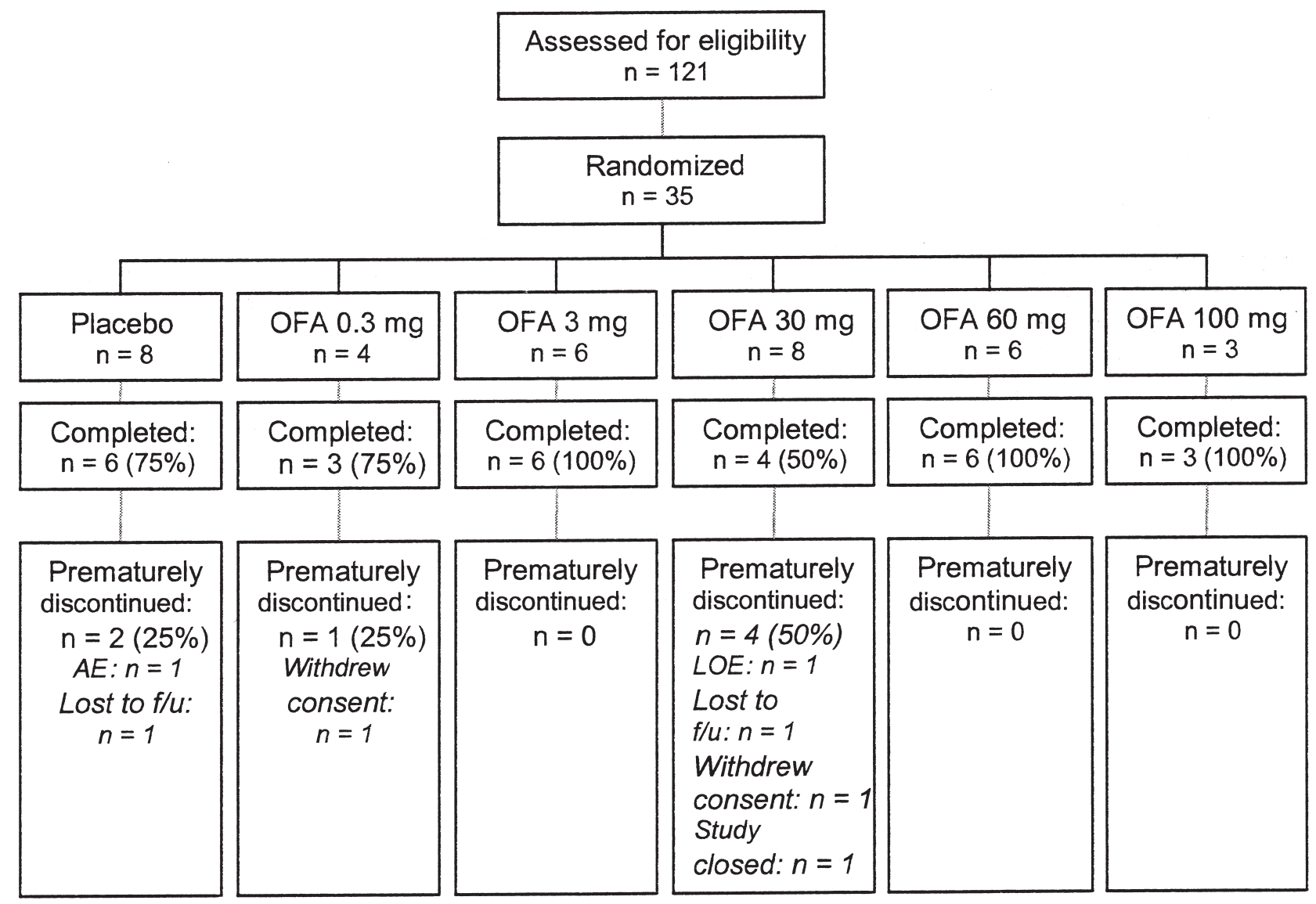

Figure 1. Patient disposition. AE: adverse event; f/u: followup; LOE: lack of efficacy; OFA: ofatumumab.

Table 1. Baseline rheumatoid arthritis patient characteristics.

\begin{tabular}{|c|c|c|c|c|c|c|c|c|}
\hline \multirow{2}{*}{ Characteristic } & & \multicolumn{7}{|c|}{ Ofatumumab } \\
\hline & & $\begin{array}{c}\text { Placebo, } \\
\mathrm{n}=8\end{array}$ & $\begin{array}{c}0.3 \mathrm{mg} \\
\mathrm{n}=4\end{array}$ & $\begin{array}{l}3 \mathrm{mg}, \\
\mathrm{n}=6\end{array}$ & $\begin{array}{c}30 \mathrm{mg}, \\
\mathrm{n}=8\end{array}$ & $\begin{array}{c}60 \mathrm{mg}, \\
\mathrm{n}=6\end{array}$ & $\begin{array}{c}100 \mathrm{mg} \\
\mathrm{n}=3\end{array}$ & $\begin{array}{l}\text { Total, } \\
\mathrm{n}=35\end{array}$ \\
\hline \multirow[t]{2}{*}{ Age, yrs } & Mean & 51.4 & 55.8 & 49.0 & 52.8 & 60.2 & 46.0 & 52.8 \\
\hline & Range & $31-71$ & $34-69$ & $22-72$ & $30-63$ & $53-78$ & $38-53$ & $22-78$ \\
\hline Sex, n (\%) & Female & $7(88)$ & $4(100)$ & $5(83)$ & $7(88)$ & $6(100)$ & $2(67)$ & $31(89)$ \\
\hline \multirow[t]{2}{*}{ Race, n (\%) } & Other ${ }^{\mathrm{a}}$ & $1(13)$ & 0 & 0 & $1(13)$ & 0 & 0 & $2(6)$ \\
\hline & White & $7(88)$ & $4(100)$ & $6(100)$ & $7(88)$ & $6(100)$ & $3(100)$ & $33(94)$ \\
\hline \multirow[t]{2}{*}{ BMI } & $\mathrm{kg} / \mathrm{m}^{2}$ & 30.01 & 30.85 & 30.46 & 27.85 & 29.54 & 30.95 & 29.69 \\
\hline & Mean SD & 3.82 & 3.60 & 6.17 & 2.16 & 7.47 & 2.41 & 4.52 \\
\hline \multicolumn{2}{|c|}{ RF-positive, n (\%) } & $7(88)$ & $1(25)$ & $3(50)$ & $6(75)$ & $2(33)$ & $2(67)$ & $21(60)$ \\
\hline Anti-CCP+ & $\mathrm{n}(\%)$ & $4(50)$ & $2(50)$ & $3(50)$ & $7(88)$ & $3(50)$ & $2(67)$ & $21(60)$ \\
\hline MTX dose & Mean (mg/wk) & 16.25 & 16.25 & 15.42 & 15.00 & 10.83 & 14.17 & - \\
\hline \multirow{2}{*}{$\begin{array}{l}\text { Prednisolone } \\
\text { dose }^{\mathrm{b}}\end{array}$} & Mean (mg/qd) & 4.75 & 5.83 & 5.00 & 7.00 & 10.00 & 0 & - \\
\hline & $\mathrm{n}$ & 4 & 3 & 1 & 5 & 2 & 0 & \\
\hline
\end{tabular}

${ }^{a}$ American Indian or Alaska native. ${ }^{b}$ Summary of steroids for patients taking steroid (prednisolone equivalent). Anti-CCP: anticyclic citrullinated peptide; RF: rheumatoid factor; BMI: body mass index; MTX: methotrexate.

temperature increase $\left(37.5^{\circ} \mathrm{C}\right)$, and mild nausea, all occurring on the day of dosing.

Three SAE (2 separate SAE of atrial fibrillation and 1 SAE of breast cancer) were reported for 1 patient in the $30 \mathrm{mg}$ group. None of the events was considered attributable to ofatumumab by the investigator. No serious infection was reported.

Liver function test elevations were reported as $\mathrm{AE}$ in 2 patients on 2 occasions. One patient in the $30 \mathrm{mg}$ group 
Table 2. Common adverse events reported by $\geq 2$ patients on treatment. Data are $\mathrm{n}(\%)$.

\begin{tabular}{|c|c|c|c|c|c|c|c|}
\hline \multirow[b]{2}{*}{ Event } & \multirow[b]{2}{*}{$\begin{array}{c}\text { Placebo, } \\
\mathrm{n}=8\end{array}$} & \multicolumn{6}{|c|}{ Ofatumumab } \\
\hline & & $\begin{array}{c}0.3 \mathrm{mg} \\
\mathrm{n}=4\end{array}$ & $\begin{array}{l}3 \mathrm{mg}, \\
\mathrm{n}=6\end{array}$ & $\begin{array}{c}30 \mathrm{mg} \\
\mathrm{n}=8\end{array}$ & $\begin{array}{c}60 \mathrm{mg}, \\
\mathrm{n}=6\end{array}$ & $\begin{array}{c}100 \mathrm{mg} \\
\mathrm{n}=3\end{array}$ & $\begin{array}{l}\text { Total, } \\
\mathrm{n}=27\end{array}$ \\
\hline Any event & $5(63)$ & $4(100)$ & $5(83)$ & $8(100)$ & $4(67)$ & $3(100)$ & $24(89)$ \\
\hline Headache & $3(38)$ & $1(25)$ & 0 & $5(63)$ & 0 & $2(67)$ & $8(30)$ \\
\hline Nausea & $1(13)$ & 0 & $1(17)$ & $3(38)$ & 0 & $2(67)$ & $6(22)$ \\
\hline $\begin{array}{l}\text { Upper respiratory } \\
\text { tract infection }\end{array}$ & $1(13)$ & $3(75)$ & 0 & $1(13)$ & 0 & $1(33)$ & $5(19)$ \\
\hline Dizziness & 0 & 0 & 0 & $2(25)$ & 0 & $1(33)$ & $3(11)$ \\
\hline Hypertension & 0 & $1(25)$ & $1(17)$ & $1(13)$ & 0 & 0 & $3(11)$ \\
\hline Pyrexia & 0 & 0 & $1(17)$ & $1(13)$ & $1(17)$ & 0 & $3(11)$ \\
\hline RA & $1(13)$ & 0 & 0 & $3(38)$ & 0 & 0 & $3(11)$ \\
\hline $\begin{array}{l}\text { Abdominal pain } \\
\text { (upper) }\end{array}$ & 0 & $1(25)$ & 0 & $1(13)$ & 0 & 0 & $2(7)$ \\
\hline Hyperhidrosis & 0 & $1(25)$ & 0 & $1(13)$ & 0 & 0 & $2(7)$ \\
\hline $\begin{array}{l}\text { Influenza-like } \\
\text { symptoms }\end{array}$ & 0 & $1(25)$ & 0 & 0 & 0 & $1(33)$ & $2(7)$ \\
\hline Laryngitis & 0 & 0 & $1(17)$ & 0 & 0 & $1(33)$ & $2(7)$ \\
\hline Urinary tract infection & 0 & $1(25)$ & 0 & $1(13)$ & 0 & 0 & $2(7)$ \\
\hline Viral infection & 0 & $2(50)$ & 0 & 0 & 0 & 0 & $2(7)$ \\
\hline
\end{tabular}

RA: rheumatoid arthritis.

developed ALT and AST elevations of $3 \times$ ULN and gamma glutamyl transferase (GGT) $2.5 \times$ ULN 6 days and elevations of ALT $3.8 \times \mathrm{ULN}$, AST of $1.6 \times \mathrm{ULN}$, and GGT 2.7 $\times$ ULN 70 days postdose. Lower MTX doses resolved both events, and they were not considered related to ofatumumab by the investigator. A patient in the $100 \mathrm{mg}$ group developed ALT and AST elevations 6 days after study drug administration, reaching a maximum ALT of $3.1 \times \mathrm{ULN}$ and AST $2.8 \times$ ULN 21 days postdose that resolved by temporarily discontinuing MTX. MTX was restarted 38 days postdose followed by an elevation of ALT $5 \times$ ULN and AST $7 \times$ ULN 41 days after dosing. MTX was discontinued and these events resolved. Both events were considered related to ofatumumab by the investigator.

No patient in the study tested positive for antidrug antibody up to 169 days postdose.
Pharmacokinetics. A summary of plasma PK measures is provided in Table 3 . A single SC dose of ofatumumab at 0.3 $\mathrm{mg}$ or $3 \mathrm{mg}$ resulted in plasma ofatumumab concentrations near or below the LLQ $(15 \mathrm{ng} / \mathrm{ml})$. After a single $\mathrm{SC}$ dose of $30 \mathrm{mg}$, $60 \mathrm{mg}$, or $100 \mathrm{mg}$, ofatumumab was slowly absorbed, with median $\mathrm{T}_{\max }$ values ranging from 4.02 to 4.49 days. Ofatumumab elimination mean half-life values ranged from 5.20 to 6.83 days. Mean maximum concentration, area under the plasma concentration curve (AUC) from administration to last observed concentration at $\mathrm{t}$, and $\mathrm{AUC}_{0-\infty}$ values for ofatumumab increased with increases in dose from $30 \mathrm{mg}$ to $100 \mathrm{mg}$. The increase was not consistently dose-proportional, possibly based on the small number of patients studied at the higher doses.

Pharmacodynamics. Median CD19+ B cell counts over time are presented in Figure 2 and indicate an increasing level of

Table 3. Summary of subcutaneous ofatumumab pharmacokinetic measures.

\begin{tabular}{|c|c|c|c|c|c|}
\hline & \multicolumn{5}{|c|}{ Ofatumumab } \\
\hline & $\begin{array}{c}0.3 \mathrm{mg} \\
\mathrm{n}=4\end{array}$ & $\begin{array}{l}3 \mathrm{mg} \\
\mathrm{n}=6\end{array}$ & $\begin{array}{c}30 \mathrm{mg}, \\
\mathrm{n}=8\end{array}$ & $\begin{array}{c}60 \mathrm{mg}, \\
\mathrm{n}=6\end{array}$ & $\begin{array}{c}100 \mathrm{mg} \\
\mathrm{n}=3\end{array}$ \\
\hline $\mathrm{Cmax}^{\mathrm{a}}(\mathrm{ng} / \mathrm{ml})$ & $\begin{array}{c}20.0 \\
(\mathrm{NA})^{\mathrm{c}}\end{array}$ & $\begin{array}{c}18.4 \\
(3.1)^{\mathrm{d}}\end{array}$ & $\begin{array}{c}827 \\
(93.3)\end{array}$ & $\begin{array}{l}1519 \\
(865)\end{array}$ & $\begin{array}{c}3405 \\
(77.2)\end{array}$ \\
\hline $\operatorname{Tmax}^{\mathrm{b}}$ (days) & $\begin{array}{c}0.497 \\
(0.50-0.50)^{\mathrm{c}}\end{array}$ & $\begin{array}{c}98.0 \\
(55.96-140.00)^{\mathrm{d}}\end{array}$ & $\begin{array}{c}4.49 \\
(2.01-7.00)\end{array}$ & $\begin{array}{c}4.49 \\
(1.00-6.98)\end{array}$ & $\begin{array}{c}4.02 \\
(4.00-5.02)\end{array}$ \\
\hline $\begin{array}{l}\operatorname{AUC}(0-\infty)^{\mathrm{a}} \\
(\mathrm{ng} / \mathrm{day} / \mathrm{ml})\end{array}$ & $\begin{array}{l}\text { NA } \\
(\mathrm{NA})^{\mathrm{e}}\end{array}$ & $\begin{array}{c}\mathrm{NA} \\
(\mathrm{NA})^{\mathrm{e}}\end{array}$ & $\begin{array}{l}7919 \\
(168)^{\mathrm{f}}\end{array}$ & $\begin{array}{l}38014 \\
(142)^{\mathrm{f}}\end{array}$ & $\begin{array}{l}50603 \\
(35.5)\end{array}$ \\
\hline Half-life $^{\mathrm{a}}$ (days) & $\begin{array}{c}\mathrm{NA} \\
(\mathrm{NA})^{\mathrm{e}}\end{array}$ & $\begin{array}{c}\mathrm{NA} \\
(\mathrm{NA})^{\mathrm{e}}\end{array}$ & $\begin{array}{c}5.20 \\
(63.0)^{\mathrm{f}}\end{array}$ & $\begin{array}{c}5.64 \\
(80.0)^{\mathrm{f}}\end{array}$ & $\begin{array}{c}6.83 \\
(45.8)\end{array}$ \\
\hline
\end{tabular}

${ }^{\mathrm{a}}$ Geometric mean $(\% \mathrm{CVb}) ;{ }^{\mathrm{b}}$ median (range); ${ }^{\mathrm{c}} \mathrm{n}=1 ;{ }^{\mathrm{d}} \mathrm{n}=2 ;{ }^{\mathrm{e}} \mathrm{n}=0$ (summary statistics not calculated); ${ }^{\mathrm{f}} \mathrm{n}=4$. NA: not applicable; Cmax: maximum concentration; AUC: area under the plasma concentration curve; Tmax: maximum ofatumumab plasma concentration. 


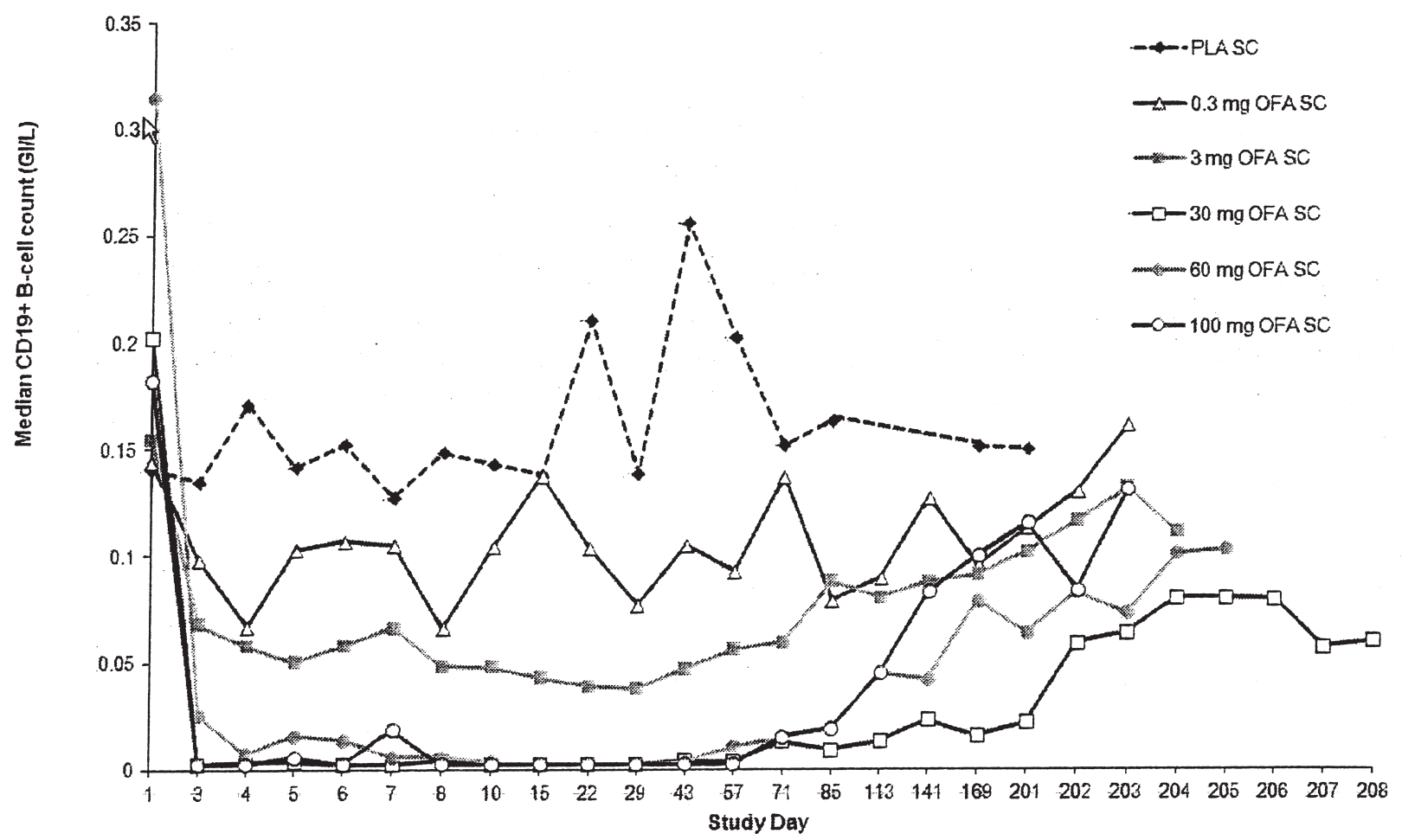

Figure 2. Median CD19+ B cell count over time (modified intent-to-treat population). One patient included in the $0.3 \mathrm{mg}$ group received an actual dose between 0.3 and $0.5 \mathrm{mg}$. Extended safety followup visits (Days 201-208) for nonrepleted patients only are displayed as nominal study days. OFA: ofatumumab; PLA: placebo; SC: subcutaneous.

CD19+ B cell depletion from the $0.3 \mathrm{mg}$ to the $30 \mathrm{mg}$ group, with profound $\mathrm{CD} 19+\mathrm{B}$ cell depletion in all 3 higher dose cohorts. Reductions in median CD19+ counts were observed at the first postdosing assessment (about $48 \mathrm{~h}$ ).

The target $\geq 95 \%$ CD19+ B cell median depletion was achieved in the $30 \mathrm{mg}, 60 \mathrm{mg}$, and $100 \mathrm{mg}$ groups at the Day 29 timepoint (Table 4). Based on individual B cell counts, $1 / 6$ patients in the $3 \mathrm{mg}$ group, $7 / 8$ in the $30 \mathrm{mg}$ group, and all patients in the $60 \mathrm{mg}$ and $100 \mathrm{mg}$ groups achieved the target CD19+ B cell depletion. A secondary assessment of depletion showed that 13 of the 17 patients who met the CD19+ B cell target depletion achieved this because of a B cell count below the LLQ (data not shown). Of the 17 patients in the $3 \mathrm{mg}, 30 \mathrm{mg}, 60 \mathrm{mg}$, and $100 \mathrm{mg}$ groups who achieved the target depletion, 14 started to replete during the study period, at 43 days to 341 days; 11 reached the repletion criterion at 113 days to 657 days (Table 4).

Baseline phenotype subset results were available for 14/17 ofatumumab B cell-depleted patients, 12 of whom had the naive phenotype (CD19+CD27-IgD+) as the predominant population at baseline. Further phenotyping of this subset showed that the majority of these cells were also CD38+CD10- (mature naive). Memory and naive B cell phenotype subsets were available for 16 ofatumumab-treated patients with postdose analyses up to 85 days postdose. All phenotypes were depleted following ofatumumab dosing, with absolute number of CD27+IgD-memory cells reduced $(<2$ cells $/ \mu 1)$ for a prolonged period in most depleted patients. Start of repletion was characterized by emergence of mainly naive phenotype (CD27-IgD+; data not shown).

There was no notable pattern for change in median systemic markers IL-6, SAA, BLC, RF, ESR, or hsCRP over time in any of the groups. For BLyS, median predose serum levels ranged from 842 to $1482 \mathrm{pg} / \mathrm{ml}$ across the dose groups. At 29 days postdose, the median levels had increased to $1984-3428 \mathrm{pg} / \mathrm{ml}$ in the B cell-depleted dose groups of 30,60 , and $100 \mathrm{mg}$.

\section{DISCUSSION}

Although new therapies are increasingly available, a significant unmet medical need continues for patients with RA who have had inadequate response to prior treatments and require safe and effective therapy using a different mechanism of action, such as B cell depletion. Rituximab is presently the only approved, B cell-depleting mAb for patients with RA. However, rituximab treatment, given as 2 IV infusions 2 weeks apart, requires IV premedication, including glucocorticoids, and several hours of infusion time, presenting a burden to patients and those involved in the administration of patients' treatment ${ }^{11}$. In addition to providing better convenience to patients, $\mathrm{SC}$ administration 
Table 4. Summary of pharmacodynamic measures: CD19+ B cells (median and median percentage change from baseline).

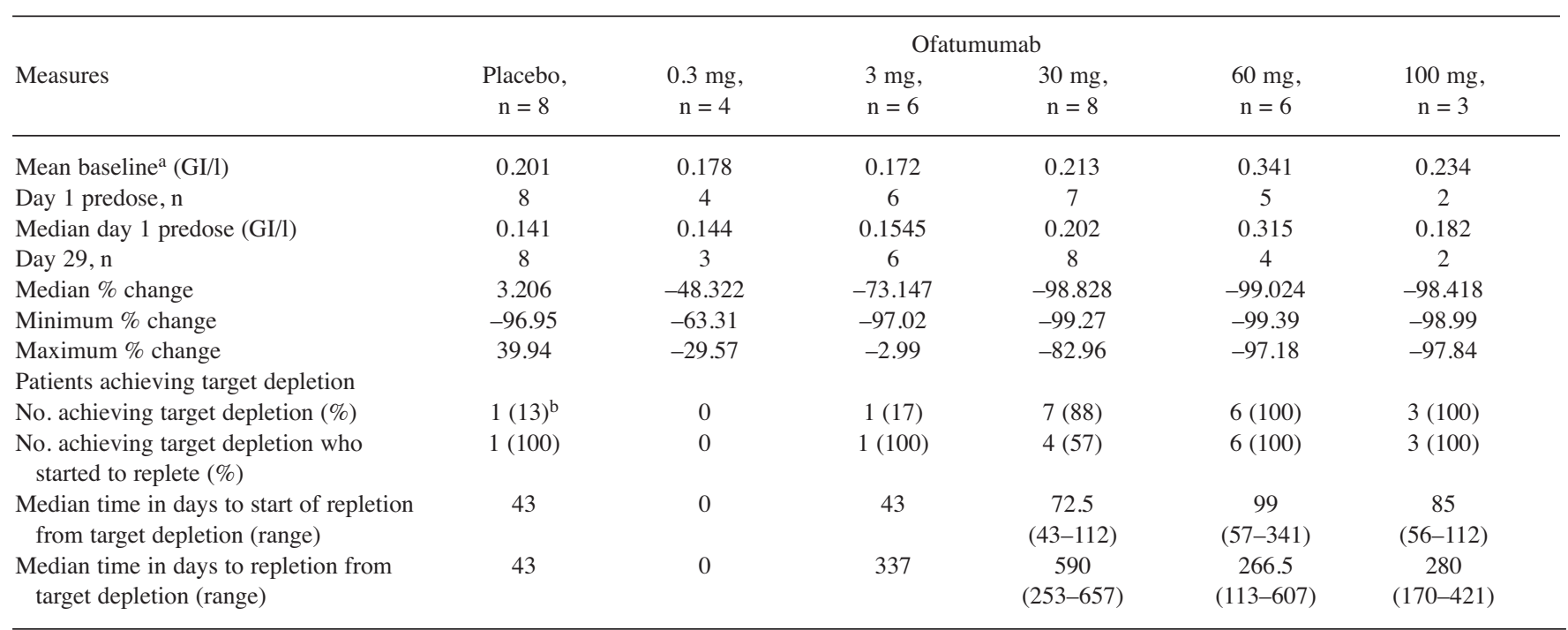

${ }^{a}$ Baseline is Day 1 predose value or the screening value if the Day 1 predose is missing. ${ }^{b}$ Placebo patient had unexplained target depletion at Day 29 and met repletion criterion at Day 43.

at a lower dose and slower rate of absorption, leading to less rapid $\mathrm{B}$ cell depletion, may result in better tolerability and less need for premedication, as has been seen with another lymphocyte-depleting monoclonal antibody, alemtuzumab ${ }^{12}$.

The safety information collected during our study suggests that SC administration of ofatumumab at doses up to $60 \mathrm{mg}$ can be tolerated with use of oral antihistamine and acetaminophen premedication, and without oral or IV glucocorticoid premedication. Although nonserious systemic injection reactions were observed more frequently in the ofatumumab-treated patients compared with placebo, they were mostly mild or moderate in intensity and manageable with use of additional oral acetaminophen or antihistamine.

For the lower doses, $0.3 \mathrm{mg}$ and $3 \mathrm{mg}$, most of the administered ofatumumab was likely cleared through target-mediated CD20 binding in the lymphatic system where the drug is likely to first present. Consequently, ofatumumab was undetectable in plasma after a single low dose of $0.3 \mathrm{mg}$ and $3 \mathrm{mg}$, and the absolute bioavailability of about $10 \%$ appears lower than might be typical for a mAb. At 30 $\mathrm{mg}$ and above, bioavailability and the overall PK profile were consistent with other subcutaneously administered antibodies ${ }^{13}$. Repeated doses of $<30 \mathrm{mg}$ in the presence of B cell depletion would be expected to increase exposure, and absolute bioavailability would increase accordingly.

Profound and prolonged B cell depletion was demonstrated with single ofatumumab doses of $30 \mathrm{mg}, 60 \mathrm{mg}$, and $100 \mathrm{mg}$. The proportion of patients achieving the target depletion was consistent with that found in studies where anti-CD20 antibodies were administered intravenously ${ }^{8,9}$. The duration of depletion to levels under 5 cells $/ \mu 1$ ranged from 22 days to $>85$ days, giving evidence of start of repletion in some patients earlier than would be expected with IV administration, which may be of clinical advantage for patients who develop infections. However, most patients did not start to replete until at least Day 43, suggesting that monthly SC dosing may be sufficient to maintain depletion in the periphery. The phenotype at baseline and of the repleting cells was predominantly naive B cells, a pattern that is also consistent with data found from IV dosing of other anti-CD20 antibodies ${ }^{14,15,16}$. It has been reported by Moller, et $\mathrm{al}^{14}$ that the sustained depletion of CD27+IgDclass switched memory B cells is associated with a good clinical response to treatment with rituximab. SC administration of ofatumumab in the current study resulted in depletion of these switched memory B cells at Day 85 .

The increase in BLyS observed with B cell depletion in the $30 \mathrm{mg}, 60 \mathrm{mg}$, and $100 \mathrm{mg}$ groups is consistent with its functions as a B cell survival factor and has been observed with rituximab-treated patients with $\mathrm{RA}^{17}$. Because our study was done with a small number of patients with RA enrolled without prespecified disease activity (e.g., elevated tender and swollen joints counts, CRP, and ESR), the lack of effect on other markers of immune status and disease activity is not unexpected.

Other anti-CD20 agents have been studied in patients with RA, including SBI-087, an agent composed of single-chain polypeptides, one-half to one-third the size of monoclonal antibodies, capable of using Fc-mediated functions. Preliminary results of a phase I study in patients with RA showed that single SC SBI-087 doses of $100 \mathrm{mg}$, $200 \mathrm{mg}$, or $300 \mathrm{mg}$, doses higher than required with SC ofatumumab, were needed to achieve B cell depletion. Fever and chills occurred following SBI-087 injection, requiring premedication and postmedication, including oral corticosteroids ${ }^{18}$. Further preliminary results from a phase II study

Personal non-commercial use only. The Journal of Rheumatology Copyright @ 2013 . All rights reserved. 
in patients with RA indicated that SBI-087 at the highest dosing regimen tested, $200 \mathrm{mg} \mathrm{SC}$, administered at 0,15 days, and 12 weeks, showed some efficacy at 16 weeks when compared to placebo ${ }^{19}$. These results support the possibility that ofatumumab, at low SC B cell-depleting doses, will demonstrate efficacy on repeat administration in present and future studies.

In our study of patients with RA taking stable doses of MTX, to our knowledge the first clinical investigation with SC ofatumumab, low doses of $30 \mathrm{mg}, 60 \mathrm{mg}$, or $100 \mathrm{mg}$ resulted in profound and prolonged peripheral B cell depletion. The observed repletion in some patients suggests that repeat dosing may be required to obtain optimal B cell depletion and the desired therapeutic response. Single doses up to $60 \mathrm{mg}$ were tolerated without glucocorticoid premedication. Because of fewer B cells available for lysis, repeat dosing is likely to result in fewer systemic reactions. SC ofatumumab $30 \mathrm{mg}$ or $60 \mathrm{mg}$ as the initial dose may therefore provide a tolerated method of achieving controlled $\mathrm{B}$ cell depletion. The results of our study have generated the data that allowed progression of repeat dosing of SC ofatumumab in multiple sclerosis and also support investigation of repeat dosing in patients with active RA.

\section{ACKNOWLEDGMENT}

The authors thank the following investigators for their participation in this study: Australia: Dr. R. Buchanan, Dr. R. Day, Dr. S. Proudman, Dr. P. Ryan; Belgium: Prof. P. Durez; France: Dr. P. Gaudin; Italy: Dr. S. Adami; Poland: Dr. S. Jeka; Russian Federation: Dr. E. Nasonov, Dr. V. Rafalsky, Dr. O. Reschova, Dr. S. Yakushin; Spain: Dr. E. Martin Mola; USA: Dr. V. Chindalore.

\section{REFERENCES}

1. Teeling JL, Mackus WJ, Wiegman LJ, van den Brakel JH, Beers SA, French RR, et al. The biological activity of human CD20 monoclonal antibodies is linked to unique epitopes on CD20. J Immunol 2006;177:362-71.

2. Genovese MC, Kaine JL, Lowenstein MB, Baldassare A, Schechtman J, Fudman E, et al. Ocrelizumab, a humanized anti-CD20 monoclonal antibody, in the treatment of patients with rheumatoid arthritis: A phase I/II randomized, blinded, placebo-controlled, dose-ranging study. Arthritis Rheum 2008;58:2652-61.

3. Goldenberg DM, Rossi EA, Stein R, Cardillo TM, Czuczman MS, Hernandez-Ilizaliturri FJ, et al. Properties and structure-function relationships of veltuzumab (hA20), a humanized anti-CD20 monoclonal antibody. Blood 2009;113:1062-70.

4. Teeling JL, French RR, Cragg MS, van den Brakel J, Pluyter M, Huang $\mathrm{H}$, et al. Characterization of new human CD20 monoclonal antibodies with potent cytolytic activity against non-Hodgkin lymphomas. Blood 2004;104:1793-800.

5. Cragg MS, Walshe CA, Ivanov AO, Glennie MJ. The biology of CD20 and its potential as a target for mAb therapy. Curr Dir Autoimmun 2005;8:140-74.
6. Glennie MJ, French RR, Cragg MS, Taylor RP. Mechanisms of killing by anti-CD20 monoclonal antibodies. Mol Immunol 2007;44:3823-37.

7. Bleeker WK, Munk ME, Mackus WJ, van den Brakel JH, Pluyter $\mathrm{M}$, Glennie $\mathrm{MJ}$, et al. Estimation of dose requirements for sustained in vivo activity of a therapeutic human anti-CD20 antibody. Br J Haematol 2008;140:303-12.

8. Ostergaard M, Baslund B, Rigby W, Rojkovich B, Jorgensen C, Dawes PT, et al. Ofatumumab, a human anti-CD20 monoclonal antibody, for treatment of rheumatoid arthritis with an inadequate response to one or more disease-modifying antirheumatic drugs: Results of a randomized, double-blind, placebo-controlled, phase I/II study. Arthritis Rheum 2010;62:2227-38.

9. Emery P, Fleischmann R, Filipowicz-Sosnowska A, Schechtman J, Szczepanski L, Kavanaugh A, et al. The efficacy and safety of rituximab in patients with active rheumatoid arthritis despite methotrexate treatment: Results of a phase IIb randomized, double-blind, placebo-controlled, dose-ranging trial. Arthritis Rheum 2006;54:1390-400.

10. Arnett FC, Edworthy SM, Bloch DA, McShane DJ, Fries JF, Cooper NS, et al. The American Rheumatism Association 1987 revised criteria for the classification of rheumatoid arthritis. Arthritis Rheum 1988;31:315-24.

11. Yazici Y, McMorris BJ, Darkow T, Rosenblatt LC. Patient and physician perception of the infusion process of the biologic agents abatacept, infliximab, and rituximab for the treatment of rheumatoid arthritis. Clin Exp Rheumatol 2009;27:907-13.

12. Osterborg A, Foa R, Bezares RF, Dearden C, Dyer MJ, Geisler C, et al. Management guidelines for the use of alemtuzumab in chronic lymphocytic leukemia. Leukemia 2009;23:1980-8.

13. Ternant D, Paintaud G. Pharmacokinetics and concentration-effect relationships of therapeutic monoclonal antibodies and fusion proteins. Expert Opin Biol Ther 2005;5 Suppl 1:S37-47.

14. Moller B, Aeberli D, Eggli S, Fuhrer M, Vajtai I, Vögelin E, et al. Class-switched B cells display response to therapeutic B-cell depletion in rheumatoid arthritis. Arthritis Res Ther 2009;11:R62.

15. Leandro MJ, Cambridge G, Ehrenstein MR, Edwards JC. Reconstitution of peripheral blood B cells after depletion with rituximab in patients with rheumatoid arthritis. Arthritis Rheum 2006;54:613-20

16. Roll P, Dörner T, Tony HP. Anti-CD20 therapy in patients with rheumatoid arthritis: Predictors of response and B cell subset regeneration after repeated treatment. Arthritis Rheum 2008;58:1566-75.

17. Cambridge G, Stohl W, Leandro MJ, Migone T, Hilbert DM, Edwards JC. Circulating levels of B lymphocyte stimulator in patients with rheumatoid arthritis following rituximab treatment. Arthritis Rheum 2005;54:723-32.

18. Fleischmann R, Cohen S, Pardo P, Dessouki E, Clowse M, Korth-Bradley J, et al. Subcutaneous (SC) administration of SBI-087 provides potent B cell depletion in subjects with controlled RA [abstract]. Ann Rheum Dis 2010;69 Suppl 3:69

19. Damjanov N, Tlustochowicz M, Aelion J, Dimic M, Greenwald M, Diehl A, et al. Safety and efficacy of SBI-087 in subjects with active rheumatoid arthritis in a phase 2 randomized, double-blind, placebo-controlled study [abstract]. Ann Rheum Dis 2012;71 Suppl 3:60. 